\title{
Peningkatan Kemampuan Pengolahan Buah Belimbing (Averrhoa Carambola L) pada Program Pengembangan Sumber Daya Lokal Berbasis Kawasan
}

\author{
Dwi Lasmining Rahayu \\ Program Studi Pendidikan Biologi FPIEK IKIP Budi Utomo Malang \\ Jalan Citandui 46 Malang
}

\begin{abstract}
Spill star fruit (carambola Averrhoa L) during the havest season to make the selling price at farmer tends to go down, so much harm to farmers starfinit. This condition gets the attention of the Provincial Government of East Java with the Development Program for Local Resource-Based Region 2009. In this program held training to overcome these problems. These training materials concerning the processing of star fruit (carambola Averrhoa L) into syrup, juice, star fruit and chips. The purpose of this study was to determine the increase in fruit processing capabilities Starfruit (carambola Averrhoa L). Object of research is the trainee of the village of Mojo, Ngringinrejo, Mojosari District of Kalitidu Bojonegoro. Instruments in this study was a questionnaire. Analysis of the data in this study using percentages and $t$-test. The results showed no increase in fruit processing capability Stanfruit (carambola Averrhoa L) which amounted to $26.23 \%$ of product knowledge, knowledge of materials $57.41 \%, 57.41 \%$ knowledge tools, materials selection $63.27 \%, 51.85 \%$ Operating tool, material processing $46.29 \%$, and $72.96 \%$ of business expectations. Increased processing capability of star fruit (carambola Averrhoa $L$ ) by $t$-test on all the indicators are very significant.
\end{abstract}

Keywords: star fruit, processing capability, selling price, training, material

Di Indonesia dibudidayakan beberapa varietas Belimbing (Averrhoa carambola L), diantaranya varietasSembiring,Siwalan, Dewi, DemakKapur, Demak Kunir, Demak Jingga, Paras Minggu, Wijaya, Paris, Filipina, Taiwan, Bangkok, dan varietas Malaysia. Tahun 1987 telah dilepas dua varietas belimbingunggulnasionalyaitu:varietas Kunir dan Kapur (Bappenas, 2008:1). Belimbing (Averrhoa carambola L) memiliki banyak manfaat yang bisa diperoleh, selain itu kandungan gizi buah belimbing cukup baik, bila dibandingkan dengan beberapa buah-buahan yang banyak dikonsumsi terutama sebagai sumber vitamin C, seperti tercantum pada tabel berikut.
Kabupaten Bojonegoro merupakan salah satu kabupaten yang menerima Program Pengembangan Sumber Daya Lokal Berbasis Kawasan (P2SLBK) tahun 2009. Lokasi penerima program ini tepatnya di tiga desa yaitu Desa Mojo, Ngringinrejo, dan Mojosari Kecamatan Kalitidu. Potensi dari desa ini adalah perkebunan Belimbing (Averrhoa carambola L) yang mencapai luas $21,5 \mathrm{Ha}$ atau dengan hasil panen bisa mencapai 698,880 ton/th. Limpahan buah pada musim panen menjadikan harga buah belimbing di petani menjadi tidak stabil dan cenderung turun, pada saat panen raya harga buah Belimbing (Averrhoa carambola L)

Tabel 1 Nilai Gizi dari Beberapa Jenis Buah-buahan Sumber Vitamin C, Setiap 100 gr bahan

\begin{tabular}{cccccccc}
\hline Jenis Buah & $\begin{array}{c}\text { Energi } \\
\text { (Kal) }\end{array}$ & $\begin{array}{c}\text { Air } \\
\text { (gr) }\end{array}$ & $\begin{array}{c}\text { Fosfor } \\
\text { (mg) }\end{array}$ & $\begin{array}{c}\text { Besi } \\
\text { (mg) }\end{array}$ & $\begin{array}{c}\text { Vit. A } \\
\text { (mg) }\end{array}$ & $\begin{array}{c}\text { Vit. B } \\
\text { (mg) }\end{array}$ & $\begin{array}{c}\text { Vit. C } \\
(\mathbf{m g})\end{array}$ \\
\hline Belimbing Manis & 86 & 90 & 12 & 11 & 170 & 0.03 & 35 \\
Jeruk & 100 & 87 & 16 & 0.2 & 420 & 0 & 49 \\
Jambu biji & 82 & 86 & 28 & 1.1 & 25 & 0.02 & 95 \\
Rambutan & 40 & 81 & 16 & 0.5 & 0 & 0 & 50 \\
Nanas & 53 & 86 & 11 & 0.3 & 130 & 0.08 & 24 \\
Pepaya & 75 & 87 & 12 & 1.7 & 365 & 0.04 & 78 \\
\hline
\end{tabular}

(Sumber: Direktorat Gizi, Departemen Kesehatan R.I. 1981 dalam Zahara, Zafni dan Kasim, Munawar, 1999:2) 
hanya berkisar antara Rp 2.000-Rp 3.000/Kg sedangkan pada saat tidak panen raya harga buah belimbing di tingkat petani bisa mencapai kisaran harga Rp 4.000-Rp 5.000/Kg.

Program Pengembangan Sumber Daya Lokal Berbasis Kawasan (P2SLBK) diarahkan ke pola pengembangan dan pengelolaan sumber daya yang meliputi: (1) Sumber Daya Alam (SDA), (2) Sumber Daya Manusia (SDM), serta Sumber Daya Ekonomi (SDE) masyarakat secara terpadu dan berkelanjutan (Bapemas_a, 2009:2). Tujuan umum program ini adalah mewujudkan kemandirian dan tanggung jawab masyarakat dalam pemanfaatan dan pelestarian sumber daya alam melalui pengembangan sumber daya lokal yang berorientasi pada percepatan pertumbuhan ekonomi, perluasan dan penciptaan lapangan kerja, serta usaha-usaha pelestariannya (Bapemas_a, 2009:5-6).

Berdasarkan permasalahan yang dihadapi masyarakat di Kabupaten Bojonegoro maka, dalam Program Pengembangan Sumber Daya Lokal Berbasis Kawasan (P2SLBK) ini memberikan solusi terhadap masalah tersebut, salah satunya adalah dengan mengadakan pelatihan pengolahan buah Belimbing (Averrhoa carambola L) menjadi produk olahan tertentu, sehingga menjadi produk olahan dengan harga yang lebih tinggi (Rahayu, 2010).

Pelatihan pengolahan buah Belimbing (Averrhoa carambola L) ini dilaksanakan selama dua hari dengan materi pengolahan buah belimbing (Averrhoa carambola L) menjadi sirup, sari buah, dan keripik belimbing. Pemateri dalam pelatihan ini dari Balai Latihan Kerja (BLK) Kabupaten Bojonegoro. Peserta pelatihan ini masyarakat dari tiga desa lokasi program (Rahayu, 2010).

\section{METODE}

Jenis penelitian ini adalah penelitian deskriptif. Objek penelitian adalah peserta pelatihan pengolahan buah Belimbing (Averhoa carambola L) dari tiga desa lokasi program yaitu Desa Mojo, Ngringinrejo, Mojosari Kecamatan Kalitidu Kabupaten Bojonegoro. Peserta pelatihan sebanyak 36 orang yang terdiri dari 18 orang dari Desa Mojo, 11 orang dari Desa Ngrnginrejo, 7 orang dari Desa Mojosari.

Tempat penelitian di Desa Mojo, Ngringinrejo, Mojosari Kecamatan Kalitidu Kabupaten Bojonegoro. Penelitian ini dilaksanakan pada tanggal 6 sampai 22 Januari 2010. Instrumen dalam penelitian ini adalah angket tertutup. Prosedur Kerja terdiri dari (a) Penyusunan Angket, (b) Pendistribusian Angket dan Pengisian Angket, (c) Pengumpulan Angket. Analisis yang digunakan adalah analisis kualitatif. Analisis data dalam penelitian ini menggunakan persentase dari masing-masing nilai indikator yang diteliti sebelum dan sesudah pelatihan, dan menggunakan uji-t untuk mengetahui signifikansinya.

\section{HASIL DAN PEMBAHASAN}

Hasil penelitian ini menunjukkan informasi tentang persentase peningkatan kemampuan peserta pelatihan pengolahan buah Belimbing (Averrhoa carambola L) sebelum dan sesudah pelatihan yang ditampilkan pada Gambar 1 .

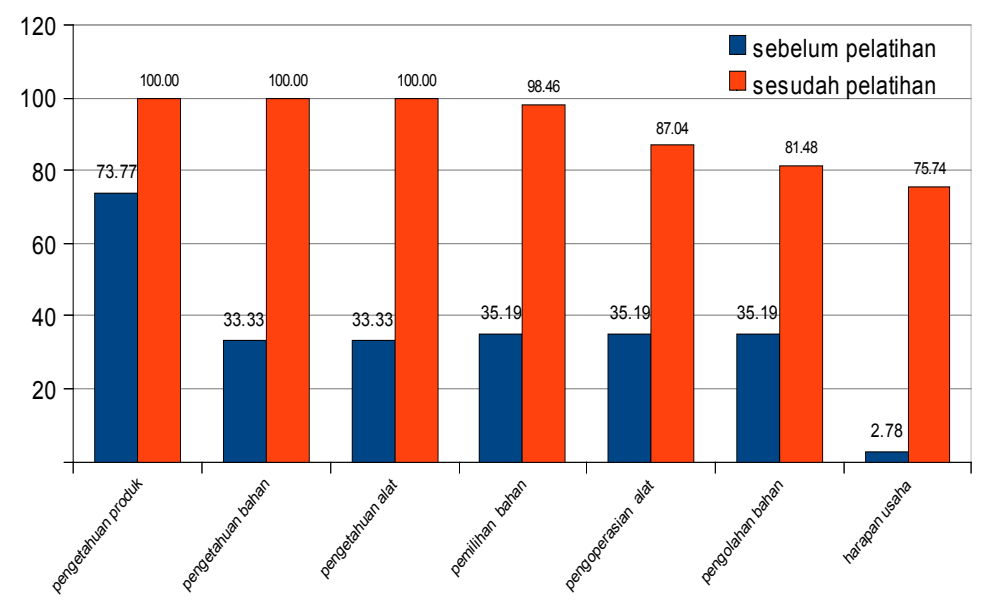

Gambar 1 Persentase Peningkatan Kemampuan Peserta Pelatihan Pengolahan Buah Belimbing (Averrhoa carambola L) Sebelum dan Sesudah Pelatihan 
Gambar 1 menunjukkan persentase peningkatan kemampuan peserta pelatihan pengolahan buah Belimbing (Averrhoa carambola L) sebelum dan sesudah pelatihan. Indikator keterampilan pengolahan buah Belimbing (Averrhoa carambola L) dalam Gambar 4.1 yaitu terdiri dari pengetahuan produk, pengetahuan bahan, pengetahuan alat, pemilihan bahan, pengoperasian alat, pengolahan bahan, harapan usaha.

Persentase pengetahuan produk sebelum pelatihan sebesar 73,77 \% dan sesudah pelatihan sebesar $100 \%$, terjadi peningkatan sebesar $26,23 \%$ dan setelah diuji menggunakan uji-t nilai hitung sebesar 7,47 yang lebih besar dari t tabel $(0,05)$ sebesar 2,19 dan $t$ tabel $(0,01)$ sebesar 2,44 sehingga sangat signifikan.

Persentase pengetahuan bahan sebelum pelatihan sebesar $42,59 \%$ dan sesudah pelatihan sebesar $100 \%$, terjadi peningkatan $57,41 \%$ dan setelah diuji menggunakan uji-t nilai hitung sebesar 26,39 yang lebih besar dari t tabel $(0,05)$ sebesar 2,19 dan $\mathrm{t}$ tabel $(0,01)$ sebesar 2,44 sehingga sangat signifikan.

Persentase pengetahuan alat sebelum pelatihan $42,59 \%$ dan sesudah pelatihan sebesar $100 \%$, terjadi peningkatan $57,41 \%$ dan setelah diuji menggunakan uji-t nilai hitung sebesar 26,39 yang lebih besar dari $t$ tabel $(0,05)$ sebesar 2,19 dan $\mathrm{t}$ tabel $(0,01)$ sebesar 2,44 sehingga sangat signifikan.

Persentase pemilihan bahan sebelum pelatihan sebesar $35,19 \%$ dan sesudah pelatihan sebesar 98,46\%, terjadi peningkatan sebesar $63,27 \%$ dan setelah diuji menggunakan uji-t nilai hitung sebesar 40,27 yang lebih besar dari t tabel $(0,05)$ sebesar 2,19 dan $t$ tabel $(0,01)$ sebesar 2,44 sehingga sangat signifikan.

Persentase pengoperasian alat sebelum pelatihan sebesar 35,19\% dan sesudah pelatihan sebesar $87,04 \%$, terjadi peningkatan sebesar $51,85 \%$ dan setelah diuji menggunakan uji-t nilai hitung sebesar 20,88 yang lebih besar dari t tabel $(0,05)$ sebesar 2,19 dan $t$ tabel $(0,01)$ sebesar 2,44 sehingga sangat signifikan.

Persentase pengolahan bahan sebelum pelatihan sebesar 35,19\% dan sesudah pelatihan sebesar $81,48 \%$, terjadi peningkatan sebesar $46,29 \%$ dan setelah diuji menggunakan uji-t nilai hitung sebesar 18,65 yang lebih besar dari t tabel $(0,05)$ sebesar 2,19 dan $t$ tabel $(0,01)$ sebesar 2,44 sehingga sangat signifikan.

Persentase harapan usaha sebelum pelatihan sebesar 2,78 \% dan sesudah pelatihan sebesar
$75,74 \%$, terjadi peningkatan $72,96 \%$ dan setelah diuji menggunakan uji-t nilai hitung sebesar 7,47 yang lebih besar dari $t$ tabel $(0,05)$ sebesar 2,19 dan $t$ tabel $(0,01)$ sebesar 2,44 sehingga sangat signifikan.

Peningkatan kemampuan peserta dalam pengolahan buah Belimbing (Averrhoa carambola L) setelah mengikuti pelatihan, dikarenakan dalam pelatihan ini menggunakan metode yang orientasi pengelolaannya berpusat pada kebutuhan peserta pelatihan atau masyarakat. Menurut Sudjana, D (1993) dalam Sudjana, D (2007:474-475). Kebutuhan utama masyarakat di lokasi program adalah kestabilan harga jual buah Belimbing (Averrhoa carambola $\mathrm{L}$ ), yang selama ini berfluktuasi. Harga jual buah Belimbing (Averrhoa carambola L) di tingkat petani pada saat panen raya hanya $\mathrm{Rp} 2.000-\mathrm{Rp} 3.000 / \mathrm{Kg}$ sedangkan pada saat tidak panen raya harga jual di tingkat petani bisa mencapai Rp 4.000Rp 5.000/Kg sehingga dengan diadakannya pelatihan pengolahan buah Belimbing (Averrhoa carambola L) ini diharapkan ada perubahan kemampuan masyarakat untuk mengolah buah Belimbing (Averrhoa carambola L) menjadi produk olahan dalam bentuk sirup, sari buah, dan keripik belimbing, dan dengan adanya peningkatan kemampuan ini diharapkan masyarakat mampu meningkatkan nilai jual buah Belimbing (Averrhoa carambola L).

Tahapan-tahapan dalam pelaksanaan pelatihan adalah sebagai berikut: (1) penyampaian harapan dan tujuan pelatihan, (2) penyampaian materi, (3) pembagian kelompok, (4) pelaksanaan kerja dalam kelompok, (5) penyajian hasil tiap kelompok, (5) evaluasi hasil tiap kelompok.

Pelatihan pengolahan buah Belimbing (Averrhoacarambola L) menunjukkan peningkatan kemampuan para peserta sebelum dan sesudah mengikuti pelatihan, baik dari indikator pengetahuan produk olahan belimbing; pengetahuan bahan yang digunakan untuk mengolah buah Belimbing (Averrhoa carambola L) menjadi sirup, sari buah, dan keripik belimbing; pengetahuan alat yang digunakan untuk mengolah buah Belimbing (Averrhoa carambola L) menjadi sirup, sari buah, dan keripik belimbing; pemilihan bahan yang berkualitas dan takaran yang tepat untuk pengolahan buah Belimbing (Averrhoa carambola L) menjadi sirup, sari buah, dan keripik belimbing; pengoperasian alat-alat yang digunakan untuk mengolah buah Belimbing (Averrhoa carambola L) menjadi sirup, sari 
66 | Dwi Lasmining Rahayu, Peningkatan Kemampuan Pengolahan Buah Belimbing ...

buah, dan keripik belimbing sesuai posedur; pengolahan bahan yang baik sesuai dengan standar kesehatan yang disarankan oleh Dinas Kesehatan (sirup, sari buah, dan keripik belimbing sudah mendapatkan No ijin dari Dinas Kesehatan); harapan usaha bagi peserta untuk mengembangkan usaha pembuatan sirup, sari buah, atau keripik belimbing baik secara mandiri atau kelompok dengan memasarkan produk yang dihasilkan melalui Show Room (toko) BKAD “Surya Abadi".

Tujuan dari pelatihan untuk meningkatkan kemampuan pengolahan buah Belimbing (Averrhoa carambola L) menjadi produk olahan tertentu (sirup, sari buah, keripik belimbing) menjadi produk olahan dengan harga yang lebih tinggi dapat tercapai. Harga jual sirup belimbing $860 \mathrm{ml}$ (botol sirup kaca) sebesar Rp 10.000 (sepuluh ribu rupiah) harga jual sari buah belimbing 240ml (gelas plastik) sebesar Rp 1.000 (seribu rupiah), dan harga jual keripik belimbing 60gr (kantung Alumunium Foil) sebesar Rp 5.000 (lima ribu rupiah). Sedangkan harga jual buah Belimbing (Averrhoa carambola $\mathrm{L}$ ) segar ditingkat petani pada saat panen raya hanya Rp 2.000-Rp $3.000 / \mathrm{kg}$ dan pada saat tidak panen raya harga jual di tingkat petani bisa mencapai Rp 4.000Rp. 5.000/kg.

Dengan diadakannya pelatihan ini telah memberikan pengaruh positif bagi peserta pelatihan, dan diharapkan dapat meningkatkan partisipasinya bagi pembangunan masyarakat (Sudjana,D,2007:471). Denganadanyapeningkatan kemampuan pengolahan buah Belimbing (Averrhoa carambola L) serta peningkatan harga jual buah Belimbing (Averrhoa carambola L) ini membuktikan bahwa pelatihan pengolahan buah Belimbing (Averrhoa carambola L) ini berhasil. Pelatihan dianggap berhasil apabila dapat membawa kenyataan atau performansi sumber daya manusia yang terlibat dalam organisasi pada saat menuju kenyataaan atau performansi sumber daya manusia yang seharusnya atau yang diinginkan oleh organisasi pelatihan (Sudjana, D, 2007:465).

\section{KESIMPULAN DAN SARAN}

Ada peningkatan kemampuan pengolahan buah belimbing (Averrhoa carambola L) melalui pelatihan Pengembangan Sumber Daya Manusia pada Program Pengembangan Sumberdaya Lokal Berbasis Kawasan di Bojonegoro yaitu pengetahuan produk sebesar $26,23 \%$, pengetahuan bahan $57,41 \%$, pengetahuan alat $57,41 \%$, pemilihan bahan $63,27 \%$, pengoperasian alat $51,85 \%$, pengolahan bahan $46,29 \%$, harapan usaha $72,96 \%$.

Berdasarkan kesimpulan di atas maka disarankan kepada peserta pelatihan sebaiknya aktif melakukan pengolahan Belimbing (Averrhoa carammbola L) baik secara mandiriatau kelompok dan memasarkan produk yang dihasilkan melalui kios BKAD "Surya Abadi", dan materi yang didapatkan dalam pelatihan sebaiknya dikembangkan lagi dengan mengadakan pelatihan lanjutan dengan materi lain misalnya tentang teknologi tepat guna untuk pengemasan dan label, atau manajemen pemasaran.

\section{DAFTAR RUJUKAN}

Bapemas_a. 2009. Draft Pedoman Umum Program Pengembangan Sumberdaya Lokal Berbasis Kawasan Propinsi Jawa Timur Tahun 2009. Surabaya: Badan Pemberdayaan Masyarakat Pemerintah Propinsi Jawa Timur.

Bappenas. 2008. Belimbing (Averrhoa carambola L). (online) (http://indomikro.com diakses 23 Maret 2010).

Sudjana, D, Tim Pengembangan Ilmu Pendidikan FIP-UPI (ed). 2007. Ilmu dan Aplikasi Pendidikan bagian 4 Pendidikan Lintas Bidang. Jakarta: PT Imperial Bhakti Utama. 